\title{
A Study on the Role of Media in Taking Right to Information Act to the Sri Lankan Masses
}

\author{
S. Sribreindran ${ }^{1}$ and G. Balasubramania Raja ${ }^{2}$ \\ ${ }^{1}$ Research Scholar, ${ }^{2}$ Professor \& Head \\ ${ }^{1 \& 2}$ Department of Communication, Manonmaniam Sundaranar University, Tirunelveli, Tamil Nadu, India \\ E-Mail: breindaranmedia@gmail.com, hodcommunication@msuniv.ac.in
}

\begin{abstract}
The Right to Information Act in 2016 is an essential milestone for Sri Lankan democracy. This new law provides an important weapon in the hands of Sri Lankan citizens, empowering them to seek any accessible information from a public authority and making the government and its functionaries more accountable and responsible. The purpose of this research is to understand and investigate the effectiveness and impact of Right to Information Act through mass media to address the issues that are challenging media to communicate. The intended objective of the research is to examine the influence of different media in communicating the Right to Information Act among the masses. When awareness on this Act is created through media, people tend to know more about it and start using it to overcome the day to day problems faced by them, thus making the objective of enacting this Act a success. This research study has made use of the survey method and content analysis to investigate the effective usage of Right to Information Act by the people and the role of media in taking the Right to Information Act to the masses. Through the survey the effectiveness of media in taking this Act to the masses is evaluated and through content analysis the actual coverage of information on RTI is evaluated and discussed. There is a significant association between frequencies of Media observation on RTI related content. There is a significant difference between age groups with respect to awareness on RTI related content by media.
\end{abstract}

Keywords: Information, Democracy, Government, Awareness

\section{INTRODUCTION}

This is the age of information explosion. The vast development in communication technology has placed information at the centre for development. The entire world is full of information, the potential of which is unlimited. The important fact is that information is meant not only for the government but also for the public. Thus the emergence of the right to information had taken place. Information is the currency that every citizen requires to participate in the life and governance of society. The access to information by the citizens will ensure the responsiveness of the government. Alternatively, the restrictions that are placed on access to information will bring about the feelings of powerlessness and alienation. If people are not information rich, they cannot adequately exercise their rights and responsibilities as citizens. Information possessed by the government is a national resource. This information is generated for purposes related to the legitimate discharge of their duties of office and for the service of the public for whose benefit the institutions of the government exists. It is the people who ultimately fund the institutions of the government and the salaries of officials. It follows that the government and officials are trustees of this information (Bapat 2013).

The right to information has a direct link with the right to freedom of expression. The right to use public sector information is considered as a part of the right to freedom of expression. In principle, the right to access to information applies to all information held by public bodies. In some countries certain databases are excluded from the scope of this right and in most of the countries the law is not very clear. On the whole, the practice varies across countries. Similarly, all countries establish a right to information in electronic format. These laws consider the general public as the legitimate owners of public information (Chandra 2007).

\section{MEDIA AND RTI}

Proper information is the primary necessity for a transparent and honest government. The right to information helps in providing this primary need and hence facilitates transparency, which is important for a democratic country like Sri Lanka. Media has a powerful impact on the acquiring of information. Media has been proved to be able to reach masses even in remote are as in a short span of time. The media monitors the functioning of the government and public officials and every other element that affects the administration. It informs and educates citizens about their rights and responsibilities, and holds the governments accountable. To perform these functions in an effective manner, the media needs to have an accurate account of events, complete and true information about various decisions at administrative level and a clear picture of the consequences of these decisions (Venkatesu 2012). For the media to work effectively, journalists should be as perfect and accountable about the information acquired as possible. There should be full verification of facts before the information is disseminated through the media. The sources of the information should be authentic, otherwise people will be misinformed. The process of acquiring or collecting information through various legal means is called investigation, and the compilation in the form of a report of the acquired information is called investigative reporting. As the 'fourth pillar of democracy', media not only has an important role in what the RTI Act claims to provide, but 
also in making sure that what is claimed is implemented, and enforced. Also, media helps in providing information to the citizens and building awareness about the RTI. In spite of the provisions that have been made to access information, citizens resort to media such as newspapers, radio, television etc. for daily information about public authorities and their activities. The media provides a link between the citizens and their government. In Sri Lanka media's right to information or right to express is not a special privilege.

\section{OBJECTIVES OF THE STUDY}

1. To identify the relationship between reading newspapers and observation on RTI related content in mass media

2. To find the impact of mass media as a source of information on RTI

3. To identify the major formats of presentation of RTI related content in newspapers and television channels.

\section{RESEARCH METHODOLOGY}

This research study has adopted the survey method deals with the methodology adopted for the study.This research to investigate the effective usage of Right to Information Act by the people and the role of media in taking the Right to Information Act to the masses. Through the survey, the effectiveness of media in taking this Act to the masses is evaluated and through content analysis, the actual coverage of information on RTI is evaluated and discussed. In survey method,

\section{A. Interviews with Journalists and Masses}

The final phase of this research involved identifying journalists who use and report on RTI and on ducting indepth interviews with a number of them and masses. who are experts in RTI, allowed them to talk the news. The level of fame of masses events or organizations also determines whether stories are newsworthy. Therefore, the prominence of particular individuals in and around government can enhance the likelihood of a story making the news. News stories can be positive or negative; however, negative stories tend to be more commonly reported in newspapers. The perceived relevance of a story to its audience is another factor which can determine whether a story becomes news. about their work. By analyzing their interviews using discourse analysis, their talk was studied as of more general interpretative practices within journalism. Here, discourse analysis.

Allowed us to systematize the different ways journalists talked about RTI. By identifying the key themes emerging within their responses we were able to make visible the common attitudes and practices Semi-Structured interviews provided insights into whether journalists' attitudes towards access and use of government-held information had changed since the implementation of RTI. Using more, these interviews provided context for the patterns, themes, tone and attitudes highlighted through the analysis.

\section{B. Right to Information in Sri Lanka}

More than one hundred countries have enacted Right to information legislation up to now. Sri Lanka enacted its own Right to information Act No. 12 in 2016 which become effective in February 2017. This was a great victory for the public since media associations and civil society organizations have been seeking such an enactment since 1994. The Colombo Declaration on media Freedom and social Responsibility of 1998 mad e this demand from the Government. It was a cornerstone of the media's crusade for good governance many believe that this law is only for journalists. It is not the case. It is nevertheless a law that gives journalists a new instrument by which they can unlock official secrets and ferret out information on behalf of the citizens.

\section{What does this mean?}

This discussion reveals that within media in Sri Lanka and RTI can be newsworthy in its own right. There are number of reasons for both positive and negative results. For instance, the power of individuals, organisations or institutions such as large government agencies dealing with complex issue like health, police, and infrastructure are likely to routinely be in information can make the news for a number of reasons, both positive and negative. For instance, the power of individuals, organisations or institutions such as large government agencies dealing with complex issue like health, police, and infrastructure are likely to routinely be in the news. The level of fame of people, events or organisations also determines whether stories are newsworthy. Therefore, the prominence of particular individuals in and around government can enhance the likelihood of a story making the news. News stories can be positive or negative; however, negative stories tend to be more commonly reported in newspapers. The perceived relevance of a story to its audience is another factor which can determine whether a story becomes news. Logically, therefore, subjects already in the news will give rise to follow up stories.

\section{Key Findings}

1. Increased media interest in open government.

2. These changing attitudes and practices offer some opportunities and potential

Challenge for RTI administrators.

3. Newspapers in Sri Lanka see RTI stories as having news value.

4. Government agencies can face a threat of double negative exposure in the news.

5. Analyse media reports and identify changes in the tone and/or orientation of media reporting, across the three key periods. 
TABLE I DISTRIBUTION OF STORIES ON RTI IN DIFFERENT SRI LANKAN MEDIA

\begin{tabular}{|c|c|c|c|}
\hline Media & Language & Date of Publication & Total \\
\hline \multirow[t]{7}{*}{ Uthyan } & Tamil & 31.03 .2017 & 07 \\
\hline & & 29.05 .2017 & \\
\hline & & 27.07 .2017 & \\
\hline & & 18.08 .2017 & \\
\hline & & 04.11 .2017 & \\
\hline & & 09.04 .2018 & \\
\hline & & 10.04 .2018 & \\
\hline The Sunday & English & 26.03 .2017 & \\
\hline \multirow[t]{7}{*}{ Times } & & 03.01 .2017 & 05 \\
\hline & & 10.09 .2017 & \\
\hline & & 17.09 .2017 & \\
\hline & & & \\
\hline & & & \\
\hline & & & \\
\hline & & & \\
\hline Mawbima & Sinhala & 19.01.2017 & 01 \\
\hline Daily Mirror & English & 06.02 .2018 & 01 \\
\hline \multirow[t]{3}{*}{ Lanka deepa } & Sinhala & 30.08 .2017 & \\
\hline & & 28.02 .2018 & 03 \\
\hline & & $\begin{array}{c}\text { Sunday lankadeepa } \\
2017 \\
\end{array}$ & \\
\hline & & & \\
\hline
\end{tabular}

\section{E. Media and Right to Information}

The media, especially in Sri Lankan plays a very important role in the society. The media is indeed the primary source of awareness so much so that the media has been started to be viewed as an entertainment as well. It is found that awareness is more broadly created through infotainment rather than just information and educational broadcasts. So, for this dissemination of information to be accurate, their access to information is of crucial importance. It acts as a connector between authority and public and is a means of mobilization (Coronel 2003). The RTI not only allows the media in playing a more constructive role in empowering people but also strengthens democratic polity. Many of the changes that have been brought about by the Act are at the most basic levels and do not come to public attention unless publicized by the media. presentation, media have three basic functions when it comes to the RTI and they are to inform and educate people about RTI, to generate debate about various issues, to disseminate a democratic culture of tolerance towards alternative points of view.
Comfortable as long as that particular interest is thoroughly protected. This Bhattarai (2011) in his conference paper, "Anti-Corruption Campaign through RTI" said that the media, being a fourth State pillar, shoulders the responsibility to make the State more accountable and transparent. As things stand now, most people are not aware of their right to freedom of information in a direct and personal way. Therefore media's role is to spread awareness, and empower the citizens to use RTI as an anticorruption weapon. When lack of proper exercise of the anti-corruption laws pose a question mark on its functioning, it becomes necessary to pay attention to the sources of information and means of communication. Information will encourage journalists and society at large to question the state of affairs. James (2009) in his article "Is Technology Networking Changing Childhood?" says that for the past five years, usage of social networking sites has increased among youth. According to a latest poll, 22\% of teenagers $\log$ in more than 10 times a day to their favourite social media sites. Social networking sites discuss various topics that lead to social change by creating awareness on the topics they discuss. One of the topics discussed often is the RTI Act.

The Information shared by the users of the social networking sites may lead to a positive impact, but there is also a negative impact of these technologies which is being discussed by Banisar (2011) in his paper "The Right to Information and Privacy: Balancing Rights and Managing Conflicts". According to him the recent communications 'technologies create and collect substantial records about individuals in the process of providing communication. Despite such misuse of technology, majority of users are inclined to use technology for discussion. Internet can be used for seeking information and this is dealt with in a paper released by the UK government on "The Guide to Freedom of Information". The Act may be valid when the request must be in writing and it can be letter or email. Also if there is a chance of making the request via web or through social networking sites such as Face book or Twitter it is relevant if the public authority also has access to these tools. Thereby stifling freedom of information where business interests are affected.

\section{E. Right to Information and Social Change}

With the rise of the Internet, Face book and blogs nowadays, common citizens are very well empowered with media, as it is more widely distributed than ever. "The Right to Information Act, 2016" stated that media being the fourth pillar of a democracy, really has the potential to bring in social change. Empowerment, social awareness and good governance are the three key areas where the media can prove to be beneficial and helpful in the upliftment of people. Public participation helps media to bring about social change. "The Right to Information Act, 2016 - A Guide for Media", media can make a real difference to the lives of poor and disadvantaged people in the following ways: 
1. Making people more aware of their rights and entitlements

2. Enabling people to have access to government programmes, schemes and benefits;

3. Making people more aware of political issues and options and helping to stimulate debate;

4. Educating the public on social, economic and environmental issues;

5. Providing a discursive space for citizens to dialogue with other actors in the governance process.

After the Internet era spread out throughout the world for sharing ideas and gathering knowledge, social media helped people to use as ineffective tool in bringing social change Mernit (2009) in his paper "Using social media for social change" describes that this is a digital age where social media has made a well-established network of audience. The social networking sites effectively follow issues in society and generate people's opinion. Net enabled social tools have enabled new models for grassroots activism and community building, and they have changed how we function in society. These web based tools have actually given voice to people to share, create, rate, and also to demand information and get it from the government. The next chapter discusses the existence of information legislations throughout the world.

\section{RECOMMENDATIONS}

1. There is very less cost involved in making all information that is available to a department/Public Authority (PA) in digital form and completely available to public. The whole information available with governments in digital form should by default be considered for proactive disclosure through digital means. Automated processes for proactive disclosure further reduce the cost of doing so. Every Information Officer (IO) can take the necessary action for converting the available information in digital form; hence disposal of request can be made easier.

2. Newspapers are effective communicators even today in the age of the dominant electronic media, contrary to the popular belief; most of them are still dependant on newspapers as the primary source of information. Awareness on RTI can be increased by having regular articles on RTI in the newspapers.

3. There is less coverage on RTI in television. By having regular reporting on RTI related news in television channels and through programmes such as documentary, discussion and features, the awareness on RTI can be increased significantly. To make RTI interesting, RTI awareness could be spread through tele - films, folk songs, serials and dedicated time slot for covering RTI stories.

\section{CONCLUSION}

Media as guardians of "freedom of speech and expression" can help eradicate this poverty of information, by disseminating accurate information in order to secure people their rightful entitlements. The general feeling amongst people is that RTI as well as the provisions related to freedom of speech and expression are more accessible to media. But as a matter of a legally accessible right, media and ordinary citizens have equal access to information under the Act. Media are the prime beneficiaries of RTI as media personnel have the time to pursue information, use it and take it to its logical conclusion. The role of media is to function as a constructive opposition in a democracy and not as an adversary of the government. Independent institutions like media can play an important and constructive role in the long-term wellbeing of the nation as they constitute the only entity within the state equipped to play such a role. With the right to information on their side, media need no longer depend on questionable sources of information, and can use RTI Act to access credible and authentic information. This legislation is a powerful tool in the hands of media to get the required information within a definite time period by applying for it. The right to information heralds a new age of investigative and authentic journalism. Both individually, and jointly mass media are instrumental in making RTI a powerful Act. When media carries information, it had credibility and people receive information about RTI mainly through various mass media. When there is regular media coverage on RTI, the awareness level will increase significantly among the Sri Lankan.

\section{REFERENCES}

[1] Bell, A., \& Garrett, P. (Eds.) (2001). Approaches to Media Discourse. Oxford. Blackwell Publishing.

[2] Fitzgerald, R., \& Housley, W. (Eds.) (2009) Media, Policy and Interaction. Alder shot. Ash gate.

[3] Harcup (2009). Journalism: Principles and practice. Second Edition. London. Sage

[4] John stone, B. (2002). Discourse Analysis. Oxford. Blackwell Publishing.

[5] Previous SLPI Publication. (2018), RTI Making the News, Colombo. 